\title{
Establishing Quaternary as a formal international Period/System
}

1 Secretary-General of International Commission on Stratigraphy, Dept. Earth and Atmospheric Sciences, Purdue University, West Lafayette, Indiana 47907-2051 USA. Email: jogg@purdue.edu

2 President, INQUA Commission on Stratigraphy and Chronology, Research School of Earth Sciences, Australian National University, Canberra, ACT 0200, Australia.Email: Brad.Pillans@anu.edu.au

Despite being the most widely used unit in field mapping and having the greatest number of active researchers, the interval known as Quaternary is unique among the chronostratigraphic subdivisions of the Geological Time Scale (GTS) in having the most controversial definition and rank. After more than 100 years of debate, the base of the Quaternary is now widely recognized at 2.6 Ma, marking a dramatic and so-far irreversible shift to the ice-age-dominated world of oscillating glacial advances over the northern continents. In 2007, both INQUA and ICS proposed that the Quaternary be established as a System of the Cenozoic Erathem, with its base defined by the GSSP of the Gelasian Stage. To maintain strict hierarchy in the GTS, it is proposed that the base of the Pleistocene Series be lowered to coincide with the Gelasian Stage GSSP at 2.6 Ma.

\section{Overview}

The Cenozoic Era currently has two ratified international periods/systems defined by global boundary stratotype sections and points (GSSPs). The Paleogene Period/System was ratified in 1991 by the International Union of Geological Sciences (IUGS) upon the acceptance of the basal-Danian GSSP. The Neogene Period/System was ratified in 1996. The interval known as Quaternary had been left undefined and without rank since 1983 upon the acceptance by IUGS of the GSSP that currently defines the base of the Pleistocene Series (base of Calabrian Stage in Mediterranean usage, ca. 1.8 Ma).

The International Union of Quaternary Research (INQUA; under the International Council for Science) and its component national members have unanimously agreed that the "Quaternary Period spans the last 2.6 million years of Earth's history" (www.inqua.tcd.ie). It begins with the first widespread continental glaciation that created deposits historically mapped as "Quaternary" and coincides with the base of the Gelasian Stage. In 2005, the International Commission of Stratigraphy (ICS) unanimously approved recognition of the Quaternary as a formal chronostratigraphic unit with its base at the Gelasian GSSP.

The ICS submitted a resolution in May 2007 to IUGS for the definition and associated rank of the Quaternary. In accordance with the IUGS requirements that establishing the Quaternary must not violate the hierarchical nature of the geological time scale and that the formalization of Quaternary must be in collaboration with INQUA, then it was necessary to simultaneously transfer the Gelasian Stage to the Pleistocene Series.

ICS recommends that IUGS establish the Quaternary as the uppermost System of the Cenozoic Erathem consistent with the usage of Quaternary by International Union for Quaternary Research (INQUA):
1) The Quaternary is a full formal chronostratigraphic unit, the appropriate status for which is the System. The underlying System is the Neogene.

2) The base of the Quaternary is placed at the current base of GSSP Gelasian Stage (currently in the Pliocene) at the base of Marine Isotope Stage (MIS) 103, which has been calibrated to an age of $\sim 2.6 \mathrm{Ma}$.

3) The base of the Pleistocene Series is lowered to coincide with that of the Quaternary System boundary (= Gelasian Stage GSSP).

4) The GSSP at Vrica, Italy (the former Plio-Pleistocene boundary), is retained as the base of the Calabrian Stage, the second stage of the revised Pleistocene Series.

In May 2007, the IUGS indicated that defining the Quaternary as a formal chronostratigraphic unit with a GSSP will be discussed further at the 2008 International Geological Congress (IGC).

In August 2007, INQUA, in unprecedented unanimous votes within both the assembly of its component national members and in a General Assembly (ca. 600 members), agreed on establishing the Quaternary as a system with its base coinciding with the present Gelasian GSSP. Therefore, the vast majority of active geoscientists in all nations that are engaged on Quaternary studies have achieved a milestone in defining the onset of this period.

The establishment of the Quaternary as a Period/System has a few controversial aspects, which is one reason that it has been without rank or accepted definition since 1983. However, INQUA and the majority of ICS considers that establishing the Quaternary as a formal period/system is consistent with its widespread usage in relation to continental deposits and establishes it as a unique interval of Earth's history in climates and human evolution.

\section{The onset of the ice ages and beginning of the Quaternary}

Despite being the most widely used unit in field mapping and having the greatest number of active researchers, the interval known as Quaternary is unique among the chronostratigraphic subdivisions in having the most controversial definition and rank (Figure 1). The convoluted history and divergent concepts of Quaternary usage is fraught with opinionated debate, beginning with the early International Geological Congresses which considered relegating Quaternary to be an un-ranked synonym for a vaguely defined Pleistocene epoch (1894) or replaced with a "Modern" period (1900). Many field workers had simply assigned a vague "Quaternary" to relatively unconsolidated material that overlies more lithified continental deposits.

The common association of Quaternary with the "Ice Ages" created another problem, because the onset of these continental glaciations is now known, from ice-rafted debris in the Greenland Sea, to have begun much earlier, in the mid-Paleogene, around 44 Ma (Tripati et al., 2008). 

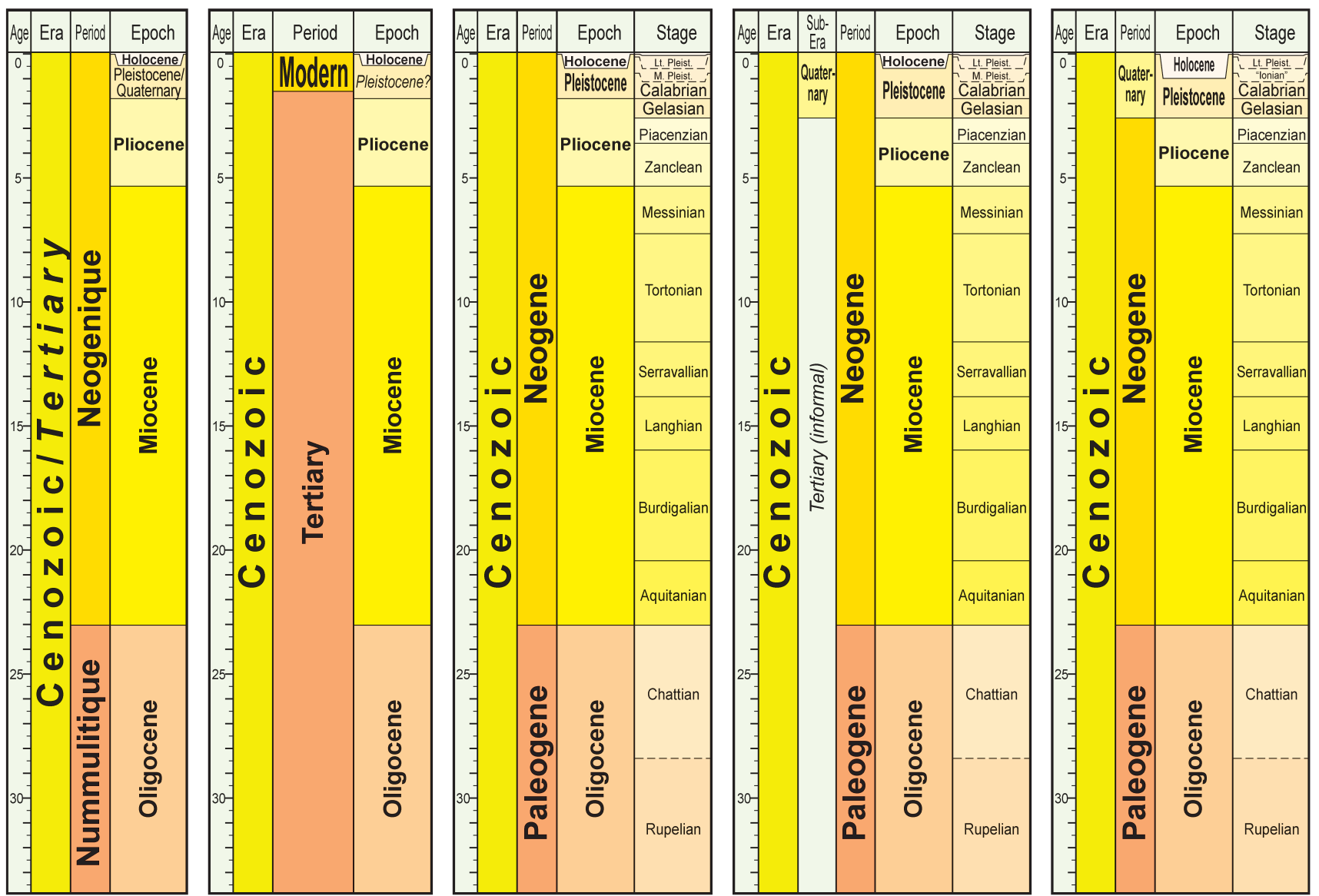

Figure 1 Selected versions of Cenozoic subdivisions and nomenclature for Oligocene-Holocene interval.

(a) 1894-The forerunner to the ICS proposed that the Cenozoic/Tertiary Era be subdivided into Nummulitique (Paleocene-Eocene-Oligocene) and Neogenique (Miocene-Pliocene-Pleistocene-Holocene); with Quaternary or Diluvium as "general synonyms" for Pleistocene (Renevier et al., 1894). The Sixth International Geological Congress (IGC) published the document, but no formal decision was made.

(b) 1900-A proposal was submitted to the Eighth IGC to subdivide Cenozoic into Tertiary and Modern periods, with Primary and Secondary retained as synonyms for the Paleozoic and Mesozoic. No formal decision was made.

(c) 1996-IUGS had ratified the Paleogene and Neogene as period/systems. During the IUGS acceptance of the Pleistocene in 1985, the Quaternary had been left without rank. INQUA defined the Quaternary as spanning the past 2.6 myr. This was the status indicated in Geologic Time Scale 2004

(d) 2005-The ICS proposes to IUGS to instate the Quaternary as a sub-era beginning with the first major "Ice Age"-the 2.6 Ma age of the earliest major continental glaciation obtained by INQUA. Under that proposal, the Tertiary would be an informal sub-era spanning the lower 95\% of the Cenozoic. This proposal, which summarized in Aubry et al. (2005), is rejected by IUGS.

(e) 2007-The ICS and INQUA jointly propose to IUGS to insert the Quaternary as a period/system using the 2.6-myr definition (base of Gelasian) voted unanimously by INQUA in 2007. To retain a hierarchical scale, the Gelasian stage is shifted to the Pleistocene. This proposal of ICS and INQUA is pending for the International Geological Congress in 2008.

In 1983, in a controversial decision, the base-Pleistocene GSSP was ratified at Vrica, Italy, near the top of the Olduvai magnetic subchron, but the decision "was isolated from other more or less related problems, such as ... status of the Quaternary" (Aguirre and Pasini, 1985). The Gelasian Stage was later created (ratified in 1996 at the 30th International Geological Congress, Beijing) to fill the "gap" between this GSSP and the "traditional" span of the Piacenzian Stage of the Pliocene Series (Rio et al., 1998). However, when the basePleistocene GSSP was established, the timing of the initial major glaciation of the Northern Hemisphere was not well understood.

The base of the Quaternary has now been established from the recognition and precise dating of glacial-driven major oxygen-isotope excursions, of pronounced eustatic lowstands on continental shelves caused by the formation of massive glacial sheets, of the onset of the main loess deposition in China, of the lowest till deposits in central USA, and of other traditional "Quaternary" deposits (Figure 2). The evidence accumulated during the past two decades is uncontroversial-at approximately 2.6 or $2.7 \mathrm{Ma}$ there was a dramatic and so-far irreversible shift to the ice-age-dominated world of oscillating glacial advances over the northern continents. This earliest major glaciation produced a major global sea-level lowstand at
2.7 Ma (major sequence boundary "Ge1" of Hardenbol et al., 1998) that coincides with cold oxygen-isotope stage 110 , and deposited the Atlanta glacial till in Missouri (e.g., Balco et al., 2005) among other widespread glacial evidence. There was also a surge in ice-rafted debris in the northern oceans, and the establishment of the modern patterns of deep-sea circulation (e.g., Haug et al., 2005; Bartoli et al., 2005). The conditions that led to this initial Ice Age probably included blocking of exchange of tropical Atlantic-Pacific waters by the formation of the Isthmus of Panama, among other tectonic and atmospheric-oceanic factors. A side effect was the emergence of bipedal humanoids; and this new generation of Lucy and her brothers has been called "Children of the Ice Age" (e.g., Stanley, 1996).

The base of the current Gelasian Stage was placed at a slightly younger level (warm interval MIS 103; age 2.59 Ma), but its association with the magnetic reversal at the onset of the Matuyama reversed-polarity Chron enables an unambiguous and precise global marker. Therefore, for expediency and unambiguous high-precision correlation between continental and oceanic deposits, the Quaternary System is being defined with this established Gelasian GSSP

Further details on the base of the Quaternary are given by Head et al. (in this Episodes volume). 


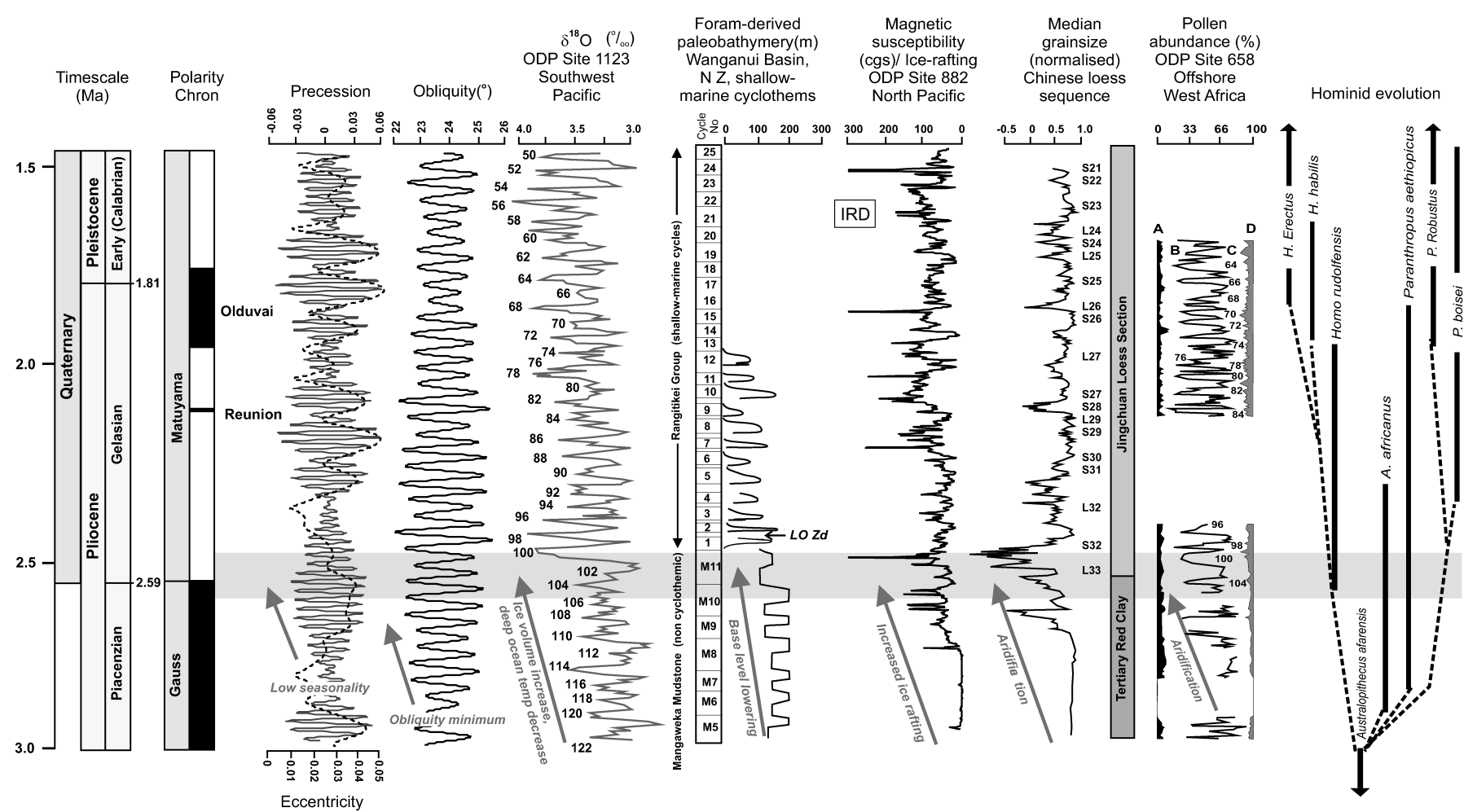

Figure 2 Temporal and latitudinal relations between orbital forcing and Earth's Late Pliocene-Early Pleistocene climate (3.0-1.5 Ma) as recorded by a high-resolution deep ocean $\delta^{18} O$ ice volume record from Southwestern Pacific ODP site 1123, glacio-eustatic cyclothems of Wanganui Basin New Zealand, ice rafting as recorded by magnetic susceptibility at North Pacific ODP site 882, and a median grainsize profile of the Jingchuan Loess Section, North central China Loess Plataeu. LO Zd denotes first appearance in North Island of New Zealand stratigraphic record of the subantarctic scallop Zygochlamys delicatula during glacial periods, traditionally marking the Plio-Pleistocene boundary in New Zealand. Pollen summary diagram from ODP 658, offshore West Africa shows progressive aridification of Northwest Africa between 2.8 and 2.4 Ma, as (B) sahel-savanna grassland and open forest elements are replaced by drier (C) saharan desert vegetation. Subordinate vegetation assemblages $(A)$ and $(D)$ represent a tropical coastal forest and "Mediterranean" (trade wind) elements, respectively. Note well-developed $40 \mathrm{ka}$ glacial-interglacial modulation of the sahel-savanna boundary following $2.6 \mathrm{Ma}$. A step-like increase in African aridity about 2.8 Ma is linked to a significant event in hominid evolution in East Africa as the genera Paranthropus and Homo emerge from a single lineage (Australopithecus afarensis). From Pillans and Naish (2004).

\section{Lowering of the Pleistocene base}

Thus, the onset of the Quaternary is nearly 800,000 years prior to the placement of the base-Pleistocene GSSP (ca. 1.8 Ma) at the level when certain cooler-water marine fauna enter the Mediterranean (Aguirre and Pasini, 1985). When this base-Pleistocene GSSP was established in 1983, there was inconclusive global evidence about the age of the earliest Quaternary glaciations. Therefore, to rectify the offset of Quaternary (as used by INQUA and its constituent international committees) and the 1983-version of the Pleistocene Epoch/Series, the ICS and INQUA agreed that the Gelasian Stage should be transferred to the Pleistocene, thereby enabling a Quaternary Period/System to be established within the Cenozoic (Figure 3). This also brings the lowered Pleistocene into better accord with the 1948 decision by the International Geological Congress Council that the Pleistocene should include the Villafranchian regional continental stage of which nearly half is currently in the late Pliocene (King and Oakley, 1949).

\section{Neogene and Tertiary}

The period/system that precedes the Quaternary is the internationally ratified Neogene. The original "Neogen ("new", "clan/birth") Stufe" of Moritz Hörnes was introduced in 1853/1864 to differentiate the younger molluscan fauna of the Vienna Basin from those of the Eocene (sensu Lyell, 1833). According to this division of the Molasse Group, the Neogene strata also included the "Knochen-Höhlen und der Löss" or glacial-derived deposits that are typical of "Quaternary" (see extended discussion by Lourens et al., 2004, and by Walsh, in press). Usage of "Neogene" by marine stratigraphers customarily includes the full suite of Miocene through Holocene epochs.

It had been recommended by Aubry et al. (2005) to establish separate Cenozoic divisions for oceanic and for continental deposits. In their scheme, the international Neogene and Paleogene periods/systems would have a parallel continental-based "sub-era" classification of the Quaternary (with its base at ca. 2.6 Ma; and offset from the marine-based Pleistocene definition) and a lengthy informal "Tertiary". This proposed duality, which would allow land-based and marine-based earth scientists to retain their own traditional schemes, was accepted by ICS in 2005 (12 Yes, 5 No $=70 \%$ Yes). However, the IUGS rejected this dichotomy proposal for two reasons. First, the IUGS was reluctant to establish a new chronostratigraphic unit ("sub-era"), and second, they ruled that any chronostratigraphic scale (hence, usage of Quaternary) must be hierarchical - the base of a higher-ranked unit must coincide with bases of all lower-ranked units, such as series/epochs. IUGS also emphasized that ICS must work with INQUA on an acceptable usage of Quaternary. The Neogene and Paleogene are ratified international periods defined by GSSPs, and INQUA was unwavering in its scientific definition of Quaternary and request that it be a period in Earth's history. Therefore, the preferred solution ( $82 \%$ Yes by ICS) was to simultaneously insert the Quaternary as a period/system that truncated the upper Neogene and to adjust the lower boundary of the Pleistocene Epoch/Series to coincide with this new Quaternary Period/System.

The term "Tertiary" is an informal grouping for the Neogene and Paleogene periods, and encompasses over $95 \%$ of the Cenozoic. As 


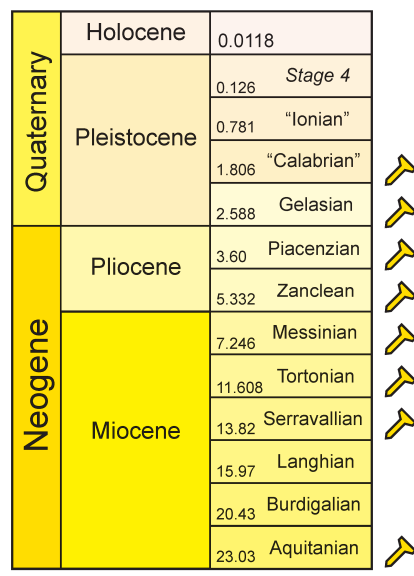

Figure 3 The proposed subdivisions of Neogene and Quaternary. The golden spikes are ratified global boundary stratotype sections and points (GSSPS). The uppermost Stage 4 of the Pleistocene will potentially be named Tarantian, after the equivalent Mediterranean regional stage. The GSSP of the current Pliocene/Pleistocene boundary at ca. 1.8 Ma will be retained as the GSSP for the Calabrian Stage.

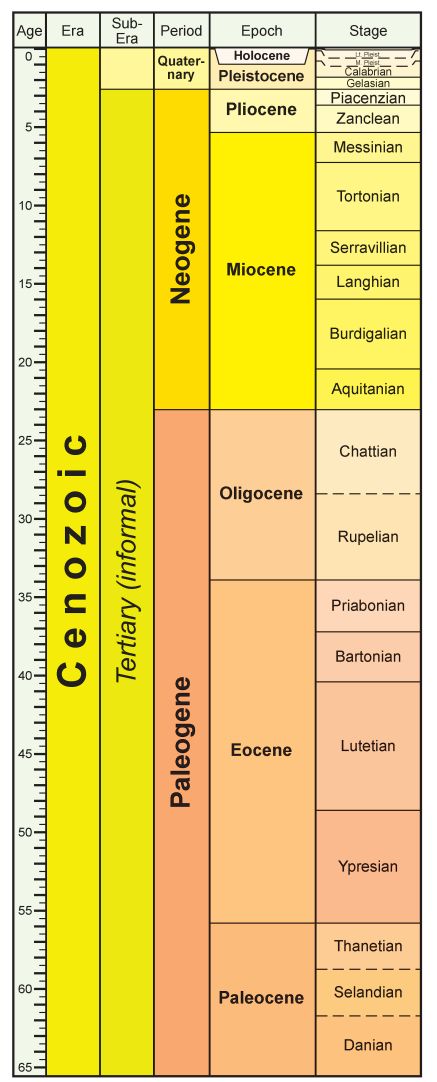

such, it is much too broad to be a useful subdivision of the Cenozoic, unless stratigraphic evidence does not allow placement of a unit or event into the international-defined Neogene or Paleogene systems.

\section{Acknowledgements}

Portions of this review were extracted from the joint ICS-IUGSINQUA task group report on Quaternary (2005), the ICS submission to IUGS requesting ratification of Quaternary as a Period (2007), extracts from historical documents in a presentation by Gian Battista Vai (2006), and from chapters and contributions to the ICS booklet "A Concise Geologic Time Scale" (Ogg et al, coordinators; 2008).

\section{References}

Aguirre, E., and Pasini, G., 1985, The Pliocene-Pleistocene Boundary: Episodes, v. 8, pp. 116-120.

Aubry, M-P., Berggren, W. A., Van Couvering, J., McGowran, B., Pillans, B., and Hilgen, F., 2005. Quaternary: status, rank, definition, survival: Episodes, v. 28, pp. 118-120.

Balco, G, Rovey II, C. W., and Stone, J. O. H., 2005. The first glacial maximum in North America: Science, v. 307, p. 222.

Bartoli G, Sarnthein M, Weinelt M, Erlenkeuser, H., Garbe-Schonberg, D., and Lea, D.W., 2005. Final closure of Panama and the onset of northern hemisphere glaciation: Earth and Planetary Science Letters, v. 237, pp. 33-44.

Berggren, W.A., 1998. The Cenozoic Era: Lyellian (chrono)stratigraphy and nomenclatural reform at the millennium, in: Blundell, D. J. and Scott, A. C. (editors), The Past is the Key to the Present: Geological Society, London, Special Publications, 143: 111-132.

Berggren, W.A., 2007. Status of the hierarchical subdivision of higher order marine Cenozoic chronostratigraphic units:Stratigraphy, v. 4, pp. 99-108.

Elias, S. A., 2007, Encyclopedia of Quaternary Science (4 volumes): Amsterdam, Elsevier.

Gibbard, P. L., Smith, A. G., Zalasiewicz, J. A., Barry, T. L., Cantrill, D., Coe, A. L., Cope, J. C. W., Gale, A. S., Gregory, F. J., Powell, J. H., Rawson, P. F., Stone, P. \& Waters, C. N. 2005, What status for the Quaternary?: Boreas, v. 34, pp. 1-6.

Hardenbol, J., Thierry, J., Farley, M. B., Jacquin, Th., de Graciansky, P.-C., and Vail, P. R. (with numerous contributors), 1998. Mesozoic and Cenozoic sequence chronostratigraphic framework of European basins, in: Mesozoic-Cenozoic Sequence Stratigraphy of European Basins (edited by de Graciansky, P.-C., Hard- enbol, J., Jacquin, Th., and Vail, P.R.), SEPM Special Publication (Tulsa), 60: 3-13, 763-781, and chart supplements.

Haug, G. H., Ganopolski, A., Sigman, D. M., Rosell-Mele, A., Swann, G. E. A. Tiedemann, R., Jaccard, S. L., Bollmann, J., Maslin, M. A., Leng, M.J., and Eglinton, G., 2005, North Pacific seasonality and the glaciation of North America 2.7 million years ago: Nature, v. 33, pp. 821-825.

King, W. B. R., and Oakley, K. P.,1949, Definition of the Pliocene-Pleistocene boundary: Nature, v. 163, p. 186

Lourens, L., Hilgen, F., Shackleton, N. J., Laskar, J., and Wilson, D, 2004, The Neogene Period, in Gradstein, F. M., Ogg, J. G., and Smith, A. G., eds, Geologic Time Scale 2004: Cambridge University Press, pp. 409-440.

Ogg, J., 2004, Introduction to concepts and proposed standardization of the term Quaternary: Episodes, v. 27, no. 2, pp. 125-126.

Pillans, B., 2004, Proposal to redefine the Quaternary: Episodes, v. 27, no.2, p. 127.

Pillans, B., and Naish, T., 2004, Defining the Quaternary: Quaternary Science Reviews, v. 23, pp. 2271-2282.

Renevier, E., 1894 (printed in 1897). Chronographe géologique: seconde édition du Tableau des terrains sédimentaires formés pendant les époques de la phase organique du globe terrestre. Compte-Rendu de la sexième session, Congrès Géologique International (Août, 1894, Zurich), printed by Georges Bridel and Co, Lausanne, in March, 1897, pp. 522-695.

Rio, D., Sprovieri, R., Castradori, D. and Di Stephano, E., 1998, The Gelasian Stage (Upper Pliocene): A new unit of the global standard chronostratigraphic scale: Episodes, v. 21, pp. 82-87.

Stanley, S.M., 1996, Children of the Ice Age: How a Global Catastrophe Allowed Humans to Evolve: Harmony publishers: 278 pp.

Tripati, A. K., Eagle, R. A., Morton, A., Dowdeswell, J. A., Atkinson, K. L., Bahe, Y., Dawber, C. F., Khadun, E., Shaw, R. M. H., Shorttle, O. and Thanabalasundaram, L., 2008, Evidence for glaciation in the Northern Hemisphere back to $44 \mathrm{Ma}$ from ice-rafted debris in the Greenland Sea: Earth and Planetary Science Letters, v. 265 , pp. 112-122.

Walsh, S. L., in press, The Neogene: origin, adoption, evolution, and controversy: Earth-Science Reviews.

\section{Selected On-Line References}

Definition and geochronologic/chronostratigraphic rank of the term Quaternary, Recommendations by the Quaternary Task Group of ICS, IUGS and INQUA (2005): www.stratigraphy.org/Q2.pdf

Quaternary Subcommission: www.quaternary.stratigraphy.org.uk, Detailed interregional chart, status of Quaternary divisions, PDFs of major articles, and other information.

INQUA, the International Union for Quaternary Research (a full Science Union member of the International Council for Science): www.inqua.tcd.ie

James G. Ogg has served as Secretary-General of the International Commission on Stratigraphy since 2000. As part of this role, he was a co-compiler of the Geologic Time Scale 2004 (Cambridge University Press, ca. 500 pages), and guided the development of the TimeScale Creator databases and visualization system (freely available at www.stratigraphy.org). James Ogg has served on nearly a dozen ocean drilling legs to explore the Mesozoic and early Cenozoic history of the Pacific, Atlantic and Indian Oceans.

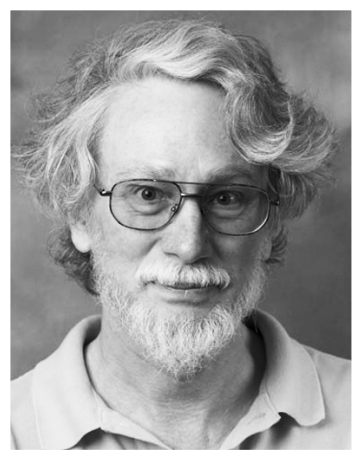

Brad Pillans is a Professorial Fellow in the Research School of Earth Sciences at The Australian National University where he runs a paleomagnetic laboratory. From 1983 to 1993 he was lecturer in Geology at Victoria University of Wellington, New Zealand. He is President of the INQUA Stratigraphy \& Chronology Commission and Chair of the ICS Working Group on the Lower-Middle Pleistocene Boundary. His research interests include geomorphology, Quaternary stratigraphy and dating methods.

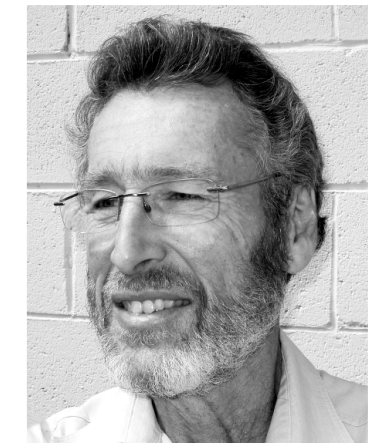

